\title{
UTJECAJ PRIJETNJI MODERNOG DOBA NA ZNAČENJE NEPOSREDNO PREDSTOJEĆEG NAPADA U KONTEKSTU PRAVA DRŽAVE NA SAMOOBRANU
}

\author{
Doc. dr. sc. Petra Perišić*
}

\author{
UDK 341.312.5 \\ https://doi.org/10.30925/zpfsr.42.3.9 \\ Ur.: 24. svibnja 2021. \\ Pr.: 27. srpnja 2021. \\ Prethodno priopćenje
}

\begin{abstract}
Sažetak
Pojava prijetnji modernog doba, kao što su terorizam ili oružje za masovno uništenje, dovela je do preispitivanja tradicionalnog shvaćanja „neposredno predstojećeg napada“, kao preduvjeta poduzimanja samoobrane. Shvaćanje „neposrednosti“ kao vremenske kategorije došlo je u pitanje upravo zbog nepredvidive naravi novih prijetnji $i$ nemogućnosti utvrđenja točnog trenutka u kojemu će se one ostvariti. Uslijed toga, kod dijela država i pravnih pisaca koncept ,neposrednosti “ doživioje reinterpretaciju, na način da se neposrednost više ne poima kao isključivo vremenska komponenta samoobrane, već se pri njenom utvrđenju uzima $u$ obzir niz različitih faktora. $U$ radu se raspravlja o tome jesu li prijetnje novog doba zaista utjecale na promjenu sadržaja zahtjeva „,neposrednosti“" samoobrane te na koji način bi takva promjena utjecala na pravo države na samoobranu.
\end{abstract}

Ključne riječi: neposredno predstojeći napad; anticipatorna samoobrana; preemptivna samoobrana; terorizam; oružje za masovno uništenje; cyber napadi.

\section{1. $U V O D$}

Iako je pravo države na samoobranu nesporno, preduvjeti njezina poduzimanja predmet su brojnih rasprava. Članak 51. Povelje Ujedinjenih naroda predviđa „prirodno pravo individualne ili kolektivne samoobrane u slučaju oružanog napada“ na nekoga člana ove Organizacije. ${ }^{1}$ Iako tekstualnim tumačenjem ove odredbe nedvojbeno dolazimo do zaključka da se oružani napad treba materijalizirati kako bi dao povoda samoobrani, a čemu ide u prilog i izvorni tekst Povelje u kojemu stoji da država ima pravo na samoobranu if an armed attack occurs..., oko takvoga tumačenja Povelje ne postoji konsenzus, niti u praksi država, niti u pravnoj znanosti. Neki

\footnotetext{
* Dr. sc. Petra Perišić, docentica, Sveučilište u Rijeci, Pravni fakultet; petra.perisic@pravri.uniri. hr. ORCID: https://orcid.org/0000-0082-8529-0152.

1 Povelja Ujedinjenih naroda, Narodne novine - Međunarodni ugovori, br. 15/93.
} 
međunarodni pravnici pristaju uz restriktivno tumačenje čl. 51., ${ }^{2}$ dok drugi smatraju da je samoobrana dopuštena i u slučaju neposredno predstojećeg napada. ${ }^{3}$ Treći, iako malobrojni, smatraju da je samoobrana dopuštena čak i u odsustvu neposredno predstojećeg napada, uz uvjet da postoji neka općenita, buduća prijetnja. ${ }^{4}$ Među onima koji zagovaraju samoobranu u slučaju neposredno predstojećeg napada postoje oni koji će takav napad podvesti pod čl. 51., smatrajući da „oružani napad“ iz ove odredbe pokriva i neposredno predstojeći napad ${ }^{5}$ i oni koji uopće ne pridaju važnost značenju i dometu „oružanog napada“ iz čl. 51. Naime, oni smatraju da potvrđivanje „prirodnog“ prava na samoobranu u navedenom članku neupitno upućuje na koegzistiranje $\mathrm{s}$ Poveljom ranije postojećeg običajnog prava na samoobranu, ${ }^{6}$ koje uključuje i obranu od neposredno predstojećeg napada, i to ako su zadovoljeni zahtjevi sadržani u poznatoj formuli Caroline. Traži se, dakle, da je napad neposredno predstojeći te da ne ostavlja vremena za razmišljanje, kao ni mogućnost drukčijeg postupanja. ${ }^{7}$

U praksi su poznati slučajevi u kojima su se države pozivale na samoobranu, iako se (još) nisu našle u ulozi žrtve oružanog napada. One su, naime, tvrdile da im je prijetila opasnost od izvjesnoga nadolazećeg napada, čija je materijalizacija bila samo pitanje vremena. Spomenimo, primjerice, relativno nedavni slučaj ubojstva iranskoga generala Kasema Sulejmanija, pri kojem se je SAD pozvao na samoobranu, $i$ to konkretno na element neposrednosti (engl. imminence),${ }^{8}$ tvrdeći da je „Sulejmani kovao neposredno predstojeće i zlokobne napade na američke diplomate i vojno osoblje“ “. ${ }^{9}$ Razlog pozivanja na neposrednost u situaciji u kojoj je očigledno nije bilo,

2 Vidi, primjerice: Ian Brownlie, International Law and the Use of Force by States (New York, London: Oxford University Press, 1963.), 278; Christine Gray, International Law and the Use of Force (New York: Oxford University Press, 2008.) 160; Albrecht Randelzhofer, „Article 51”, $\mathrm{u}$ : The Charter of the United Nations - A Commentary, ur. Bruno Simma (Oxford, New York: Oxford University Press, 1995.), 676.

3 Vidi, primjerice: Derek W. Bowett, Self-Defense in International Law (New York: Frederic A. Praeger, 1958.), 187-192; Thomas M. Franck, Recourse to Force: State Action against Threats and Armed Attacks (Cambridge, New York: Cambridge University Press, 2002.), 98; Louis Henkin et al., Right v. Might: International Law and the Use of Force (New York: Council on Foreign Relations Press, 1991.), 40-47.

4 John Alan Cohan, „The Bush Doctrine and the Emerging norm of Anticipatory Self-Defense in International Law", Pace International Law Review 15, br. 2 (2003): 354.

5 Vidi, primjerice: Francis A. Boyle, „Military Responses to Terrorism”, Proceedings of American Society of International Law 81 (1987): 294.

6 Vidi, primjerice: Terry D. Gill, „The Temporal Dimension of Self-Defense: Anticipation, Preemption, Prevention and Immediacy", Journal of Conflict and Security Law 11, br. 3 (2006): 361.

7 Kada su britanske snage upale na američki teritorij i zapalile parobrod Caroline koji je pružao pomoć pobunjenicima protiv britanske vlasti u Kanadi, pozivajući se na samoobranu, američki državni tajnik Webster izjavio je kako tada konkretno nisu bili ispunjeni uvjeti za poduzimanje samoobrane, a to su, kako navodi, da je samoobrana instant, overwhelming, leaving no choice of means and no moment for deliberation. Michael N. Schmitt, „Preemptive Strategies in International Law", Michigan Journal of International Law 24 (2003): 529.

8 U ovom ćemo radu pojam imminence prevoditi kao „neposrednost“, dok ćemo izraz imminent attack prevoditi kao „neposredno predstojeći napad“. O uporabi relevantnih pojmova vidi više infra, poglavlje 2.1.

9 Trump says Soleimani plotted 'imminent' attacks, but critics question just how soon, pristup 
jest taj što se u praksi SAD-a neposrednost tradicionalno smatrala nužnim preduvjetom poduzimanja samoobrane.

Iako se države redovito pozivaju na argument neposredno predstojećeg napada, vidljivo je da se njihovo poimanje neposrednosti često razlikuje od tradicionalnog shvaćanja ovoga zahtjeva, prema kojemu se neposrednost smatrala vremenskom komponentom samoobrane. Razlog je takve promjene pojava novih prijetnji i izmijenjeni modus napada na državu. Naime, napadi su u današnje vrijeme često iznenadni, i u trenutku kada pogode državu žrtvu, ona više nema učinkovitog načina obraniti se. Teroristički napadi u pojedinim državama primjer su toga, kao i prijetnje oružjem za masovno uništenje.

Pojedine države počele su zagovarati stajalište da neposrednost kod prijetnji modernog doba ne treba procjenjivati samo prema vremenskoj blizini predstojećeg napada, već da se ispunjenje zahtjeva neposrednosti treba procjenjivati i postavljanjem sljedećeg pitanja: Koji je trenutak posljednja prilika (engl. last window of opportunity) da se osujeti budući napad? Prema takvom shvaćanju, oružani se napad smatra neposredno predstojećim ako je odgovor na taj napad nužan sada, neovisno o tome kada će se budući napad dogoditi.

U ovom radu nastojat ćemo dati kratki osvrt na utjecaj prijetnji modernog doba na element neposrednosti samoobrane. Zapitat ćemo se jesu li te prijetnje zahtjev neposrednosti zaista izmijenile ili ga možda čak učinile suvišnim i je li, posljedično, opravdano smatrati da su se zahtjevi neposrednosti i nužnosti stopili u jedan jedinstveni zahtjev, koji bi sadržajno odgovarao zahtjevu nužnosti.

\section{ZAHTJEV NEPOSREDNOSTI (engl. IMMINENCE)}

\subsection{Značenje pojma neposrednosti}

Kada govorimo o neposrednosti u kontekstu samoobrane, odnosno o postojanju neposredno predstojećeg napada, općenito mislimo na napad koji se treba dogoditi u skoroj budućnosti, s time da nije jasno je li riječ o satima, danima ili nekom još dužem razdoblju. Pokušamo li takvo općenito određenje neposredno predstojećeg napada raščlaniti i pojasniti, nailazimo na poteškoće. Usporedba značenja pojma imminent u različitim rječnicima engleskog jezika implicira njegove različite sadržaje. Tako Oxford rječnik kaže kako je neposredno predstojeći događaj „onaj koji će se dogoditi“ (engl. about to happen) ${ }^{10}$ dok je prema Cambridge rječniku riječ o događaju „koji je nadolazeći ili je izgledno da će se vrlo uskoro dogoditi“ (engl. coming or likely to happen very soon). ${ }^{11}$ Iz takvih je pojmovnih određenja razvidno da je neposredno predstojeći napad u prvom navedenom slučaju označen kao onaj koji će se sigurno dogoditi, dok je u drugom slučaju tek izgledno da će do njegova nastupanja doći, što

13. siječnja 2021., https://www.reuters.com/article/us-iraq-security-blast-intelligenceidUSKBN1Z228N.

10 Oxford Dictionary, pristup 15. siječnja 2021., https://www.lexico.com/definition/imminent.

11 Cambridge Dictionary, pristup 15. siječnja 2021., https://dictionary.cambridge.org/dictionary/ english/imminent. 
znači da možda i neće. ${ }^{12}$

Slična je situacija i kod prijevoda pojma imminent na hrvatski jezik. Imminent je pojam koji se uvijek povezuje s pojmovima opasnosti, prijetnje i napada. Možemo ga prevesti kao „,izravan“, „neposredan“, „neizbježan“, „predstojeći“, „prijeteći“, „neminovan“. ${ }^{13}$ To je, dakle, svakako napad koji se treba dogoditi, iako nije sasvim jasno kada i s kojim stupnjem izvjesnosti. Različiti prijevodi imaju različite implikacije u tom smislu. Tako, primjerice, ,prijeteći“ napad nije toliko izvjestan kao „,neizbježan“ ili „neminovan“ napad, a činjenica da je napad ,prijeteći“ ne implicira nužno da je vremenski vrlo blizak. Možemo zaključiti iz svega navedenoga da pojmovno razjašnjenje neposrednosti nije nedvosmisleno.

Unatoč navedenim nedorečenostima, čini se nespornim da se u pravnoj doktrini i u praksi država neposrednost tradicionalno smatrala vremenskom komponentom samoobrane. ${ }^{14} \mathrm{U}$ već spomenutoj formuli Caroline rečeno je da nužnost samoobrane mora biti „trenutna“ (engl. instant) i da „ne ostavlja vremena za razmišljanje“. I stajalište je nekih pravnih autora da je neposrednost praktički sinonim za trenutačnost (engl. immediacy). ${ }^{15}$ Ipak, ovdje treba ukazati na jedno važno razlikovanje. Naime, kada govorimo o trenutačnosti (engl. immediacy), valja razlikovati situacije u kojima se trenutačnost odnosi na prijetnju, od onih u kojima se ona odnosi na odgovor $u$ samoobrani. U prvom slučaju, trenutačnost se poistovjećuje s neposrednošću pa govorimo o preventivnom djelovanju protiv napada koji se tek treba materijalizirati i koji je, stoga, uvijek budući. U drugom slučaju, riječ je o zahtjevu da se samoobrana poduzme bez vremenske odgode protiv napada koji je u tijeku. ${ }^{16}$

Neposrednost, prema nekim autorima, podrazumijeva i ,specifičnu“ i „,prepoznatljivu“ prijetnju. ${ }^{17} \mathrm{Uz}$ to, prema Izvješću Neovisne međunarodne misije za utvrđivanje činjenica u sukobu u Gruziji, napad koji daje povoda samoobrani mora biti „objektivno provjerljiv“ $\mathrm{i}$,,konkretno neposredno predstojeći“. ${ }^{18}$

O značenju pojma neposrednosti raspravljalo se i pred Međunarodnim sudom u predmetu Gabčikovo-Nagymaros Project, iako ne u kontekstu upotrebe sile, već u kontekstu ugovornog prava. Sud je tada kazao kako je neposrednost sinonim za trenutačnost (engl. immediacy) i blizinu (engl. proximity) i da premašuje koncept

12 Usporedbu značenja neposredno predstojećeg napada prema različitim rječnicima engleskog jezika vidi u: Noam Lubell, „The Problem of Imminence in an Uncertain World”, u: The Oxford Handbook of the Use of Force in International Law, ur. Marc Weller (Oxford: Oxford University Press, 2015.), 703.

13 Milica Gačić, Englesko-hrvatski rječnik prava, međunarodnih odnosa, kriminalistike $i$ forenzičnih znanosti, kriminologije i sigurnosti (Zagreb: Naklada Ljevak, 2004.), 636.

14 Mark L. Rockefeller, „The „Imminent Threat Requirement for the Use of Preemptive Military Force: Is it Time for a Non-temporal Standard?", Denver Journal of International Law and Policy 33 (2004): 131.

15 Rockefeller, The Imminent Threat Requirement for the Use of Preemptive Military Force, 131.

16 Military and Paramilitary Activities in and Against Nicaragua (Nicaragua v. United States of America), Merits, Judgment, ICJ Reports 1986, para. 237.

17 Lubell, The Problem of Imminence in an Uncertain World, 708.

18 Report of the Independent International Fact-finding Mission on the Conflict in Georgia, vol. 2, pristup 19. siječnja 2021., https://www.mpil.de/files/pdf4/IIFFMCG_Volume_II1.pdf. 
mogućnosti (engl. possibility). ${ }^{19}$ Ipak, Sud nije isključio mogućnost da se i dugoročna opasnost smatra neposrednom, ako je nastupanje te opasnosti sigurno i neizbježno. ${ }^{20}$ Takvo stajalište Suda, međutim, treba promatrati u kontekstu predmeta o kojemu se raspravljalo. Budući da je ovdje bilo riječi o potencijalnoj opasnosti za okoliš, stajalište je Suda bilo sukladno s načelom predostrožnosti (engl. precautionary principle), koje se i inače primjenjuje u pravu zaštite okoliša. Ono, međutim, nije primjenjivo u kontekstu upotrebe sile. Pogrešno bi bilo pretpostaviti da bi se stajalište iz presude Gabčikovo-Nagymaros Project moglo analogijom primijeniti na upotrebu sile, ${ }^{21}$ osobito uzevši u obzir to da je Međunarodni sud u svojoj dosadašnjoj praksi uvijek bio oprezan kada je raspravljao o pitanjima upotrebe sile, ne izjašnjavajući se o spornim pitanjima o kojima se nije bilo nužno očitovati u konkretnim predmetima koji su se našli pred njim. ${ }^{22}$

\subsection{Neposrednost kao zahtjev dopustive samoobrane}

Nesporno je da je samoobrana dopuštena kod istovremenoga protupravnog napada. ${ }^{23}$ Kada bi ona bila poduzeta nakon što se napad već dogodio, ne bi bilo riječ o obrani, već o međunarodnim pravom zabranjenim oružanim represalijama. ${ }^{24}$ $\mathrm{S}$ druge strane, poduzimanje samoobrane prije no što je do protupravnog napada uopće došlo dovelo bi do preventivne samoobrane, koja je, u najmanju ruku, sporna. Ipak, nisu svi slučajevi preventivne samoobrane isti. U nekima se države pozivaju na samoobranu anticipirajući njome, kako tvrde, neposredno predstojeći napad. U drugim se slučajevima pozivaju na samoobranu protiv prijetnji za koje s većom ili manjom sigurnošću tvrde da će se materijalizirati u nekom budućem trenutku, za kojega se ne zna kada će točno nastupiti. Zbog takvih različitih okolnosti u kojima države mogu djelovati preventivno pozivajući se na samoobranu, nastao je niz termina koji označavaju različite vrste samoobrane. Tako se u literaturi spominju pojmovi interceptivne, anticipatorne, preemptivne i preventivne samoobrane. Riječ je o tehničkim, a ne pravnim terminima, koji se među pravnim autorima dosljedno ne upotrebljavaju. Stoga je čest slučaj da različiti autori tim pojmovima pridaju različita

19 Gabčykovo-Nagymaros Project (Hungary v. Slovakia), Judgment, ICJ Reports, 1997., 7.

20 Gabčykovo-Nagymaros Project, para. 54.

21 Neki se autori, međutim, na zaključke iz presude Gabčikovo-Nagymaros Project pozivaju i u kontekstu prava na samoobranu. Vidi: Dapo Akande i Thomas Liefländer, „Clarifying Necessity, Imminence and Proportionality in the Law of Self-defense”, American Journal of International Law 107, br. 3 (2013): 565.

22 Primjerice, u presudi o Nikaragvi, Međunarodni je sud kazao kako se neće izjašnjavati o legalnosti samoobrane protiv neposredno predstojećeg napada, s obzirom na to da države $u$ sporu nisu postavile to pitanje, već su se fokusirale na napad koji se već dogodio. ICJ Reports 1986, para. 194.

23 Joe Boyle, „Making Sense of Self-Defence in the War on Terror“, Journal on the Use of Force and International Law 1, br. 1 (2014): 62.

24 Deklaracija o načelima međunarodnog prava o prijateljskim odnosima i suradnji između država u skladu s Poveljom UN, GA Res 2625 (XXV), 1970. Vidi i: Roberto Barsotti, „Armed Reprisals“, u: The Current Legal Regulation of the Use of Force, ur. Antonio Cassese (Dordrecht: Martinus Nijhoff Publishers, 1986.), 79. 
značenja te da, prije no što se upuste u raspravu o njima, daju određena pojmovna razjašnjenja. ${ }^{25}$ Iako ćemo u ovom radu staviti fokus samo na zahtjev neposrednosti i nećemo se upuštati u širu raspravu o svakome od navedenih fenomena, ipak je nužno i ovdje dati neka pojmovna određenja, s obzirom na to da se neposrednost nalazi u središtu rasprave o svim modalitetima preventivne samoobrane.

Pojam preventivne samoobrane koristit ćemo kao krovni pojam koji obuhvaća sve slučajeve u kojima je navodna samoobrana poduzeta prije no što se dogodio protupravni napad. Pod anticipatornom samoobranom shvaćamo onu samoobranu koja je prethodila neposredno predstojećem napadu. Preemptivna samoobrana označava, tzv. Bushevu doktrinu, odnosno samoobranu protiv budućih prijetnji, čija je materijalizacija neizvjesna i vremenski daleka. Interceptivna samoobrana je situacija u kojoj je protupravni napad već otpočeo, ali još nije pogodio teritorij države žrtve. Ovu bismo vrstu samoobrane, iako ju se često promatra u kontekstu preventivne samoobrane, bili skloni izjednačiti sa samoobranom temeljenom na čl. 51. Povelje, odnosno onom poduzetom u odgovoru na oružani napad. Ako vizualiziramo ovaj slučaj kroz situaciju ispaljivanja rakete s područja države agresora, pri čemu raketa još nije pogodila državu žrtvu, možemo zaključiti da je oružani napad već započeo i da će bez sumnje pogoditi državu žrtvu.

Prije pojave koncepta preemptivne samoobrane, pitanje dopustivosti preventivne samoobrane svodilo se u osnovi na raspravu o anticipatornoj samoobrani, odnosno onoj kojom se odgovara na neposredno predstojeći napad. Prije donošenja Povelje UN-a 1945., običajno pravo na samoobranu u slučaju neposredno predstojećeg napada svakako je postojalo. Ono je izraženo već spomenutom formulom Caroline. Donošenjem Povelje i predviđanjem uvjeta „oružanog napada“ u čl. 51. došlo je do razilaženja u shvaćanjima oko toga je li opća prihvaćenost Povelje i njenog čl. 51. označila kraj dotadašnjeg shvaćanja samoobrane koja je dopuštena u slučaju neposredno predstojećeg napada, i početak novog shvaćanja, prema kojemu je to pravo ograničeno na slučajeve oružanog napada.

Među pravnim autorima, vidjeli smo, nema konsenzusa oko ovoga pitanja.

Iz prakse tijela Ujedinjenih naroda također ne možemo izvući nedvosmisleni zaključak o njemu. Međunarodni sud, iako se na neki način izjasnio protiv preemptivne samoobrane, ${ }^{26}$ propustio je izjasniti se o dopustivosti anticipatorne samoobrane. Vijeće sigurnosti se, očekivano, izjašnjavalo samo o konkretnim slučajevima u kojima su se države pozivale na samoobranu. Ipak, iz stajališta Vijeća sigurnosti može se zaključiti da preemptivna samoobrana nije prihvaćena, ali da bi anticipatorna mogla biti. Naime, kada je Izrael napao irački nuklearni reaktor Osirak 1981. pozivajući se na samoobranu, taj je čin naišao na osudu Vijeća sigurnosti ${ }^{27}$ jer je nedostajao

25 Vidi, primjerice: Terry D. Gill, „The Temporal Dimension of Self-Defense: Anticipation, Preemption, Prevention and Immediacy", Journal of Conflict and Security Law 11, br. 3 (2006): 362-363.

26 U predmetu DR Congo v. Uganda Međunarodni sud navodi: Article 51 ... does not allow the use of force by a State to protect perceived security interests ... te je uputio države na obraćanje Vijeću sigurnosti u slučaju takve navodne ugroze. Vidi: Armed Actvities on the Territory of the Congo (DR Congo v. Uganda), ICJ Reports, 2005, para. 148.

27 SC Res 487 (1981). 
element neposrednosti (engl. imminence). S druge strane, kada je Izrael 1967. napao Egipat, djelujući tako protiv očekivanog neposredno predstojećeg napada Egipta, Vijeće sigurnosti tek je pozvalo strane u sukobu na okončanje neprijateljstava, no nije osudilo čin Izraela. ${ }^{28}$

Na tragu shvaćanja o dopustivosti samoobrane protiv neposredno predstojećeg napada bio je bivši glavni tajnik Ujedinjenih naroda, Kofi Annan. On je oformio radnu skupinu pod nazivom United Nations High-Level Panel on Threats, Challenges and Change, koja je 2004. usvojila izvješće u kojemu se, između ostaloga, dotakla pitanja neposredno predstojećeg napada. U Izvješću se konstatiralo da, sukladno s međunarodnim običajnim pravom (engl. long established international law), država koja je ugrožena može poduzeti vojnu akciju ako je prijeteći napad neposredno predstojeći (engl. imminent), ako ga se ne može spriječiti drugim sredstvima i ako je proporcionalan. ${ }^{29} \mathrm{~S}$ druge strane, ako država smatra da postoji opasnost od napada koji nije neposredno predstojeći (engl. non-imminent or non-proximate), ona se može obratiti Vijeću sigurnosti, koje može dati odobrenje za preventivnu upotrebu sile. ${ }^{30}$ U svom Izvješću iz 2005., glavni tajnik jasno navodi da su „neposredno predstojeće prijetnje potpuno pokrivene čl. 51. Povelje, koji štiti prirodno pravo suverenih država da se obrane od oružanog napada“. Pritom je dodao da je uvriježeno shvaćanje pravnika da pravo na samoobranu pokriva i slučajeve neposredno predstojećeg napada, kao i onoga koji se već dogodio. ${ }^{31}$

Ipak, stajalište glavnog tajnika nije bilo prihvaćeno u Općoj skupštini UN-a. U rezoluciji kojom se usvaja Završni akt Svjetskog summita iz 2005., konstatiralo se tek da su „relevantne odredbe Povelje dovoljne za reagiranje na širok spektar prijetnji međunarodnom miru i sigurnosti“ 32

Praksa država bogata je slučajevima pozivanja na samoobranu, no ona zapravo ne poznaje slučajeve u kojima je napad bio do te mjere izvjestan da se je mogao smatrati neposredno predstojećim, u smislu formule Caroline. Jedini slučaj koji se tome približio bio je Šestodnevni rat 1967. između Izraela i Egipta. Međutim, čak i tada, argument neposredno predstojećeg napada iznijeli su pravni autori, dok je Izrael tvrdio da je djelovao u odnosu na postojeći oružani napad. ${ }^{33}$ Vidjeli smo, s druge strane, da je akcija Izraela protiv iračkoga nuklearnog reaktora Osiraka 1981. doživjela osudu u Vijeću sigurnosti, upravo stoga što je nedostajao element neposrednosti. ${ }^{34} \mathrm{U}$ slučajevima u kojima je SAD isticao argument samoobrane, kao što je, primjerice, bila invazija na Irak 2003. ili spomenuti slučaj ubojstva iranskoga generala

28 SC Res 233 (1967).

29 AMoreSecureWorld:OurSharedResponsibility,ReportoftheSecretary-General'sHigh-levelPanel on Threats, Challenges and Change (2004), pristup 10. veljače 2021., https://www.un.org/ ruleoflaw/files/gaA.59.565_En.pdf.

30 A More Secure World, para. 189-190.

31 In Larger Freedom: Towards Development, Security and Human Rights for All, Report of the Secretary-General, 124, pristup 11. veljače 2021., https://www.un.org/en/events/pastevents/ in larger_freedom.shtml.

32 GA Res 60/1.

33 Gray, International Law and the Use of Force, 161.

34 Anthony Clark Arend i Robert J. Beck, International Law and the Use of Force: beyond the UN Charter Paradigm (London/New York: Routledge, 1993.), 78-79. 
Sulejmanija 2020., nije moglo biti riječi o dopustivoj samoobrani, između ostaloga, zbog nepostojanja neposredno predstojećeg napada. ${ }^{35} \mathrm{U}$ navedenim slučajevima osuda SAD-a u Vijeću sigurnosti izostala je iz očitog razloga - statusa SAD-a kao stalne članice Vijeća sigurnosti s pravom veta. Ipak, u sklopu Ujedinjenih naroda ubojstvo Sulejmanija doživjelo je osudu. Posebni izvjestitelj UN-a za izvansudska, prijeka ili proizvoljna pogubljenja u svojem je Izvješću osudio napad, kazavši da nije bilo nikakvih dokaza o postojanju trenutačnog ili neposredno predstojećeg napada. ${ }^{36}$ Retorika glavnog tajnika bila je nešto blaža. On je pozvao na oprez i suzdržanost, baš kao i većina država međunarodne zajednice. ${ }^{37}$

\section{ZAHTJEV NEPOSREDNOSTI I PRIJETNJE MODERNOG DOBA}

\subsection{Prijetnje modernog doba - terorizam, oružje za masovno uništenje, cyber napadi}

Napadi koji karakteriziraju moderno doba razlikuju se od onih koji su obilježavali veliki dio ljudske povijesti. Međudržavni sukobi, koji su započinjali vidljivom mobilizacijom vojske, i u kojima je, stoga, bilo više ili manje jasno kada bi napad pojedine države mogao započeti, nisu više prevladavajući oblici ratovanja. U današnje vrijeme, međunarodna zajednica suočava se s novim oblicima prijetnji, među kojima istaknuto mjesto imaju terorizam, korištenje oružja za masovno uništenje i cyber napadi. Za razliku od vidljive vojske koja se koncentrira na državnoj granici i priprema napad, ovi se napadi pripremaju „nevidljivo“ i u tajnosti, a u trenutku kada se dogode, mogu prouzročiti goleme ljudske i materijalne gubitke.

Pojava svake od ovih novih prijetnji otvorila je brojna pitanja i ovdje se nećemo upuštati u raspravu o svakome od njih. ${ }^{38}$ Koncentrirat ćemo se samo na njihov utjecaj na poimanje zahtjeva neposrednosti.

Kada je riječ o terorističkim napadima, sama njihova bit protivna je zahtjevu neposrednosti. S obzirom na to da nastupaju iznenadno, tu ne može biti govora o poduzimanju samoobrane protiv neposredno predstojećeg napada jer se, iz perspektive države žrtve, ne zna kada će napad nastupiti. Ipak, i kod terorističke aktivnosti, situacije se mogu razlikovati. Može se, s jedne strane, raditi o konkretnim predstojećim napadima, za koje postoje pouzdane informacije da će uskoro nastupiti, a može biti riječi o općenitoj bojazni od budućih terorističkih napada. U prvom bi

$35 \mathrm{Za}$ analizu Sulejmanijeva ubojstva u kontekstu prava na samoobranu vidi: The Soleimani Strike and Self-defense against an Imminent Armed Attack, pristup 20. veljače 2021., https://www. ejiltalk.org/the-soleimani-strike-and-self-defence-against-an-imminent-armed-attack/.

36 Report of the Special Rapporteur on Extrajudicial, summary or arbitrary executions, Use of Armed Drones for Targeted Killings, A/HRC/44/38, pristup 23. veljače 2021., https://undocs. org/en/A/HRC/44/38.

37 World reacts to US killing of Iran's Qassem Soleimani in Iraq, pristup 25. veljače 2021., https:// www.aljazeera.com/news/2020/1/3/world-reacts-to-us-killing-of-irans-qassem-soleimani-iniraq.

38 Jedno od najspornijih pitanja koje se javlja u kontekstu prijetnji novog doba jest može li se samoobrana uopće poduzeti u slučaju njihova nastupanja, ako one ne dolaze od države, već od nedržavnih aktera, što najčešće i jest slučaj. 
slučaju moglo biti riječi o postojanju neposredno predstojećeg napada, dok u drugome ne bi. To, dakako, ne isključuje primjenu mjera provođenja zakona kako bi se osujetile buduće prijetnje.

Osim u kontekstu terorizma, zahtjev neposrednosti biva podvrgnut preispitivanju i u kontekstu upotrebe oružja za masovno uništenje, odnosno biološkog, kemijskog, radioaktivnog ili nuklearnog oružja. Upotreba toga oružja može, ali i ne mora biti povezana s terorizmom. No neovisno o tome koristi li se ono u sklopu terorističke aktivnosti ili klasičnog oružanog sukoba, karakterizirano je iznimno razornim učinkom. ${ }^{39}$ Upotreba ove vrste oružja, koje se ,lako prikriva, tajno prenosi i upotrebljava bez upozorenja“", bila je jedan od glavnih razloga zbog kojih su neke države prilagodile zahtjev neposrednosti ,mogućnostima i ciljevima današnjih neprijatelja“" ${ }^{40}$ Tako je, primjerice, američka invazija na Irak 2003. bila pravdana primarno suzbijanjem prijetnje upotrebe oružja za masovno uništenje. ${ }^{41} \mathrm{U}$ daljnjem izlaganju o promijenjenom shvaćanju neposrednosti zbog novih prijetnji vidjet ćemo da je upravo težina napada, odnosno težina povreda koje on može prouzročiti, jedno od mjerila kojim se procjenjuje postojanje neposredno predstojećeg napada.

Konačno, među novijim prijetnjama, koje se smatra jednim od razloga za promjenu koncepta neposrednosti, nalaze se cyber napadi, odnosno napadi počinjeni putem računalnih mreža, $i$ to s političkim ciljem ili ciljem ugrožavanja nacionalne sigurnosti. ${ }^{42} \mathrm{Uz}$ već spomenuti problem nepredvidivosti nastupanja, koji karakterizira sve suvremene prijetnje, ovdje se javlja i dodatni moment - dvojba oko toga mogu li se cyber napadi uopće smatrati „oružanim napadom“ u smislu čl. 51. Povelje, i mogu li, posljedično, aktivirati pravo na samoobranu. Iako do sada niti jedna država nije tvrdila da je cyber predstavlja oružani napad, ${ }^{43} \mathrm{u}$ pravnoj doktrini postoje shvaćanja da ,neki oblici cyber napada mogu sačinjavati oružani napad, opravdavajući upotrebu sile u samoobrani". ${ }^{44}$

Rasprava oko ovog pitanja išla je primarno u smjeru utvrđivanja toga može li cyber napad po svojoj težini i intenzitetu doseći razinu oružanog napada. S jedne strane, takvo je utvrđenje nužno, s obzirom na činjenicu da napad, kao što je utvrdio Međunarodni sud u predmetu Nicaragua, mora biti određenog intenziteta kako bi dao povoda samoobrani. ${ }^{45} \mathrm{~S}$ druge, pak, strane, utvrđivanje težine napada čini se opravdanim tek ako utvrdimo da je riječ o oružanom napadu, budući da postoji konsenzus oko toga da je samo oružana sila, a ne i drugi oblici prisile (primjerice

39 Yoram Dinstein, War, Aggression and Self-Defense (Cambridge: Cambridge University Press, 2012.), 204.

40 National Security Strategy 2002, 15.

41 David P. Fidler, „International Law and Weapons of Mass Destruction: End of the Arms Control Approach?", Duke Journal of Comparative \& International Law 14 (2004): 40.

42 Oona A. Hathaway et al., „The Law of Cyber-Attack”, California Law Review 100, br. 4 (2012): 826. Vidi i: Jay P. Kesan i Carol M. Hayes, „Mitigative Counterstriking: Self-Defense and Deterrence in Cyberspace", Harvard Journal of Law and Technology 25, br. 2 (2012): 417.

43 Hathaway, The Law of Cyber-Attack, 840.

44 Ryan J. Hayward, „Evaluating the Imminence of a Cyber Attack for Purposes of Anticipatory Self-Defense", Columbia Law Review 117 (2017): 405.

45 ICJ Reports 1986, para. 195. 
politička ili ekonomska), ${ }^{46}$ zabranjena Poveljom UN-a. U tom smislu, valjalo je dati odgovor na pitanje što je uopće oružje i može li se cyber napad potpasti pod taj pojam. Iako danas nema jedinstveno prihvaćene definicije oružja, neki su autoru skloni smatrati kako se oružjem mogu kvalificirati i neka nekonvencionalna sredstva ratovanja, ako ona mogu prouzročiti uništenje ljudi i imovine. ${ }^{47}$ Ako potencijal nanošenja povrede uzmemo kao kriterij procjene oružja, tada bi se i cyber napad mogao smatrati oružanim napadom.

\subsection{Promjene u shvaćanju zahtjeva neposrednosti}

Kazali smo već da se neposrednost tradicionalno smatrala vremenskom komponentom samoobrane. Uz običajnopravne zahtjeve nužnosti i proporcionalnosti, zagovornici dopustivosti samoobrane u slučaju neposredno predstojećeg napada smatraju ju trećim uvjetom za procjenjivanje opravdanosti samoobrane, neovisnom o prethodna dva. Da je riječ o zasebnom zahtjevu, govori činjenica da neki oružani napad može biti neposredno predstojeći, no samoobrana ipak nije opravdana jer nedostaje zahtjev nužnosti (primjerice, spor je moguće riješiti i sredstvima koja ne uključuju upotrebu sile). Suprotno, može se tvrditi da samoobrana jest nužna, u smislu da ne postoji drugačiji način otklanjanja budućeg napada, ali napad nije neposredno predstojeći pa nedostaje element neposrednosti. ${ }^{48}$

Nakon terorističkih napada 11. rujna takvo se poimanje neposrednosti počelo mijenjati. Iako se do toga trenutka mogućnost samoobrane, čak i za one koji su ju shvaćali ekstenzivno, povezivala s neposredno predstojećim napadom, taj se zahtjev $\mathrm{u}$ diskursu primarno SAD-a počeo relativizirati. Busheva doktrina, promovirana u Strategiji nacionalne sigurnosti iz 2002., pomaknula je granice samoobrane mnogo dalje od odgovora na neposredno predstojeći napad, predvidjevši mogućnost preemptivnog djelovanja protiv navodnih budućih opasnosti, neovisno o vremenu njihove moguće realizacije. ${ }^{49} \mathrm{U}$ govoru o stanju nacije 2003. Bush je izričito najavio napuštanje zahtjeva neposrednosti napada kao uvjeta poduzimanja samoobrane. On je tada naveo: „Neki kažu da ne smijemo djelovati sve dok prijetnja ne postane neposredno predstojeća. Od kada teroristi i tirani najavljuju svoje namjere i pristojno nas obavještavaju prije no što napadnu?"“. 50

Stajalište SAD-a prema preemptivnoj samoobrani ponovljeno je i u Strategiji nacionalne sigurnosti iz 2006. ${ }^{51}$ Eksplicitno je rečeno kako samoobrana podrazumijeva

46 Randelzhofer, Article 51, 112.

47 Brownlie, International Law and the Use of Force by States, 362.

48 Lubell, The Problem of Imminence in an Uncertain World, 3.

49 The National Security Strategy of the United States of America, 2002, pristup 5. ožujka 2021., https://2009-2017.state.gov/documents/organization/63562.pdf. Iako je doktrina preemptivne samoobrane jasno istaknuta u navedenoj Strategiji, njezini se začetci javljaju i ranije. O tome više u: $\quad$ W. Michael Reisman i Andrea Armstrong, ,The Past and Future of the Claim of Preemptive Self-Defense", American Journal of International Law 100, br. 3 (2006): 527.

50 US Department of State Archive: The Bush's Administration Non-Ploriferation Policy: Successes and Future Challenges, pristup 5. ožujka 2021., https://2001-2009.state.gov/t/us/ $\mathrm{rm} / 31029 . \mathrm{htm}$.

51 The National Security Strategy of the United States of America, 2006, pristup 8. ožujka 2021., 
i upotrebu sile prije no što se napad dogodi, čak i kod nesigurnosti o tome kada i gdje će neprijatelj napasti. Diskursom koji svakako više podsjeća na postavke doktrine pravednog rata, no na suvremeno pravo na samoobranu, u Strategiji se navodi kako će „razlozi djelovanja biti jasni, sila odmjerena, a svrha pravedna“. ${ }^{52}$

Široko shvaćanje zahtjeva neposrednosti zadržalo se i u vrijeme Obamine administracije. John Brennan, tadašnji pomoćnik predsjednika za Nacionalnu sigurnost, izjavio je kako je potrebno fleksibilnije shvaćanje neposrednosti u borbi $\mathrm{s}$ terorističkim skupinama, s obzirom na to da neposrednost koja se zahtijevala $\mathrm{u}$ tradicionalnim sukobima više nije primjerena za prijetnje koje dolaze od nedržavnih aktera. ${ }^{53}$ Ipak, čini se da Obama nije tek naslijedio Bushevu doktrinu preemptivne samoobrane, već je zauzeo umjereniji stav. U Izvješću iz 2016., ${ }^{54}$ on se pozvao na, tzv. „Bethlehemova načela“ $\mathrm{u}$ formuliranju kriterija za pribjegavanje samoobrani $\mathrm{u}$ slučaju neposredno predstojećeg napada, iz čega je vidljivo da neposrednost shvaća šire od temporalnosti, ali ne toliko široko da opravda samoobranu protiv vremenski dalekih i neizvjesnih prijetnji. ${ }^{55}$

SAD nije ostao izoliran u zagovaranju promijenjenog odnosa prema značenju neposredno predstojećeg napada. Ujedinjeno Kraljevstvo zauzelo je stajalište da se koncept neposredno predstojećeg napada treba mijenjati kako bi odgovorio na nove okolnosti i nove prijetnje. Države bi, prema tome, mogle poduzeti samoobranu ako postoje dokazi o neposredno predstojećim terorističkim napadima, čak i ako nema posebnih dokaza o tome gdje će napad nastupiti i koja će točno biti priroda toga napada. ${ }^{56}$ Odstupanje od tradicionalnog shvaćanja neposrednosti vidljivo je i iz govora britanskoga glavnog državnog odvjetnika, Jeremyja Wrighta, iz 2017. On je izjavio kako se u slučaju napada koji se još nije dogodio, nužnost djelovanja u samoobrani procjenjuje i prema tome je li napad neposredno predstojeći. Pritom će se neposrednost nastupanja napada procjenjivati prema tome je li odgovor u samoobrani nužan u trenutku njezina poduzimanja. ${ }^{57}$ Iste je godine australski glavni državni odvjetnik, George Brandis, održao javni govor na temu prava na samoobranu protiv neposredno predstojećeg napada, ističući da istupa u ime australske vlade. Brandis je istaknuo da Australija ne podržava ideju preemptivne samoobrane, već one anticipatorne, dakle, zagovara mogućnost samoobrane protiv neposredno predstojećeg napada, a ne i

https://georgewbush-whitehouse.archives.gov/nsc/nss/2006/.

52 The National Security Strategy, 2006.

53 Remarks of John O. Brennan, „Strengthening Our Security by Adhering to our Values and Laws “, pristup 10. ožujka 2021., https://obamawhitehouse.archives.gov/the-press-office/2011/09/16/ remarks-john-o-brennan-strengthening-our-security-adhering-our-values-an.

54 Report on the Legal and Policy Frameworks guiding the United States' Use of Military Force and Related National Security Operations, pristup 12. ožujka 2021., https://www. justsecurity.org/wp-content/uploads/2016/12/framework.Report_Final.pdf. Izvješće se poziva na „Bethlehemova načela“, o kojima vidi infra.

55 Raspravu o tome vidi u: Aiden Warren i Ingvild Bode, „Altering the Playing Field: The US Redefinition of the Use of Force", Contemporary Security Policy 36, br. 2 (2015): 174.

56 Gray, International Law and the Use of Force, 215.

57 Attorney General's speech at the International Institute for Strategic Studies, pristup 15. ožujka 2021., https://www.gov.uk/government/speeches/attorney-generals-speech-at-theinternational-institute-for-strategic-studies. 
„protiv prijetnji koje se još nisu kristalizirale, ali koje bi se nekada u budućnosti mogle materijalizirati““ ${ }^{58}$ Međutim, obrazlažući pojam neposredno predstojećeg napada, on koristi njegovo prošireno značenje i ističe kako pitanje neposrednosti nije isključivo pitanje vremena. Pri procjeni ispunjavanja zahtjeva neposrednosti, smatra Brandis, treba uzeti u obzir i druge okolnosti, primjerice koji je posljednji trenutak u kojem se može poduzeti samoobrana protiv prijetećeg napada. Potporu takvom shvaćanju pojma neposrednosti Brandis nalazi u dvama dokumentima: Tallinn Manual, kojega je sastavila ekspertna skupina, a koji obuhvaća pravila međunarodnog prava primjenjiva na cyber ratovanje te Chatham House načelima međunarodnog prava o upotrebi sile u samoobrani, koja su sastavila skupina međunarodnih stručnjaka.

I Tallinn Manual i Chatham House načela zasnivaju se na netemporalnom shvaćanju neposrednosti. Oba dokumenta polaze od toga da je samoobrana dopuštena u onom trenutku kada država procijeni da bi propuštanje djelovanja u samoobrani baš u tom trenutku onesposobilo državu da se učinkovito obrani onda kada napad zaista i nastupi ${ }^{59} \mathrm{U}$ tom smislu, prema Chatham House načelima, ,nužnost određuje neposrednost" . ${ }^{60}$ Takvo shvaćanje neposrednosti svakako dovodi u pitanje samostalnu primjenjivost toga zahtjeva i čini ga tek jednim od čimbenika za procjenu nužnosti.

Predstavnici država koje zagovaraju netemporalno shvaćanje neposrednosti pozvali su se u svojim argumentacijama na načela koja je vezano uz domet prava na samoobranu formulirao bivši pravni savjetnik $\mathrm{u}$ britanskom Foreign and Commonwealth Office, Daniel Bethlehem. Bethlehem je, konstatirajući doktrinarnu podijeljenost između pravnih autora, predložio šesnaest načela kojima bi se države trebale rukovoditi pri procjeni opravdanosti pribjegavanja samoobrani. ${ }^{61}$ Osmo od navedenih načela odnosi se na zahtjev neposrednosti i predviđa procjenu sljedećih okolnosti pri utvrđivanju njegova ispunjenja: a) prirodu i trenutačnost (engl. immediacy) prijetnje, b) vjerojatnost napada, c) procjenu je li prijeteći napad dio ustaljenog obrasca kontinuirane oružane aktivnosti, d) izgledni razmjer napada $i$ povreda, gubitka ili štete koji će proizaći iz njega, e) vjerojatnost drugih mogućnosti poduzimanja učinkovite akcije u samoobrani, koje bi prouzročile manje ozbiljne

58 The Right of Self-Defence against Imminent Armed Attack in International Law, pristup 16. ožujka 2021., https://www.ejiltalk.org/the-right-of-self-defence-against-imminent-armedattack-in-international-law/.

59 Nicholas Tsagourias, „Chapter 2: The Tallinn Manual on the International Law Applicable to Cyber Warfare: A Commentary on Chapter II - The Use of Force", Yearbook of International Humanitarian Law 15 (2012): 35; Chatham House Principles of International Law on the Use of Force by State in Self-defense, pristup 18. ožujka 2021., https://www.chathamhouse.org/ sites/default/files/publications/research/2005-10-01-use-force-states-self-defence-wilmshurst. pdf.

60 Tsagourias, Chapter 2: The Tallinn Manual on the International Law Applicable to Cyber Warfare, 35.

61 Predložena načela, za razliku od Chatham House načela ili Leiden Policy Recommendations, moguće odražavaju stavove pojedinih vlada, s obzirom na to da i sam Bethlehem navodi kako su rezultat rasprava s različitim državnim dužnosnicima, iako je nejasno u kojoj mjeri ova načela odražavaju pozicije država. Vidi: International Law and the Use of Force, pristup 22. ožujka 2021., https://legal.un.org/avl/pdf/ls/Wood_article.pdf. 
kolateralne povrede, gubitak ili štetu. ${ }^{62}$

Bethlehem navodi niz okolnosti koje valja uzeti u obzir u procjeni neposrednosti. Riječ je o utvrđivanju trenutačnosti, prirode i težine napada, ${ }^{63}$ ali i utvrđivanju je li napad „dio ustaljenog obrasca kontinuirane oružane aktivnosti“. Ovaj posljednji kriterij pridonosi, rekli bismo, dodatnoj fleksibilizaciji zahtjeva neposrednosti. Polazi se, naime, od toga da u situaciji niza okončanih napada, nastupanje sljedećega potencijalnog napada treba promatrati u kontekstu već očitovane namjere napadanja. Budući napad, stoga, ne treba promatrati izolirano, već kao dio jednoga jedinstvenog produljenog napada. $U$ trenutku kada se prvi u nizu napada dogodio, ne treba se pitati je li novi napad neposredno predstojeći, već ,ima li država žrtva dovoljno pouzdanih dokaza... da su budući napadi izgledni“". ${ }^{64}$

Pozivanje na takav „dvojaki“ karakter samoobrane, pri čemu se ona poduzima i kao odgovor na već pretrpljeni napad i kao prevencija budućega napada, razmjerno je često u praksi država. Na ovaj se argument po prvi puta pozvao Izrael sedamdesetih godina prošlog stoljeća, opravdavajući oružanu akciju kojom je odgovorio na niz manjih napada Palestinske oslobodilačke organizacije. ${ }^{65}$ Izrael se nastavio pozivati na ovu teoriju i kasnije, s obzirom na to da se više puta našao na meti sporadičnih višestrukih napada koji su dolazili iz okolnih područja nedržavnih aktera. ${ }^{66}$ Ali na teoriju kumuliranih događaja pozivale su se i neke druge države, kao što su Južna Afrika, Portugal i SAD. ${ }^{67}$ Jedan od najistaknutijih primjera takvog djelovanja bila je upravo oružana akcija SAD-a u Afganistanu 2001. ${ }^{68}$

Međunarodni se sud u nekoliko predmeta dotaknuo pitanja niza oružanih napada, iako se u svakome od njih zadržao na okolnostima slučaja i nije se izjašnjavao o teoriji kao takvoj. U presudi o Nikaragvi, Sud je raspravljao o tome mogu li se prekogranični upadi u Honduras i Kostariku, koji su pripisivi Nikaragvi, smatrati oružanim napadom, bilo gledajući ih izolirano ili kumulativno. ${ }^{69}$ Rješavajući u predmetu $O$ naftnim platformama, Sud je također raspravljao o mogućnosti oružanog napada koji se sastoji od niza napada, no ni u ovom se slučaju iz konteksta i formulacije tog dijela

62 Daniel Bethlehem, ,Self-Defense Against an Imminent or Actual Armed Attack by Nonstate Actors", American Journal of International Law 106, br. 4 (2012): 770-777.

63 Ovi kriteriji za procjenjivanje neposrednosti formulirani su već ranije. Vidi: Leiden Policy Recommendations on Counter-terrorism and International Law, pristup 22. ožujka 2021., https://scholarlypublications.universiteitleiden.nl/access/item\%3A3145048/view.

64 Michael Schmitt, „Counter-Terrorism and the Use of Force in International Law”, u: International Law Studies, ur. Fred L. Borch i Paul S. Wilson, 79 (2003): 32. Vidi i: Authorization for Use of Military Force after Iraq and Afghanistan, pristup 25. ožujka 2021., https://www.foreign. senate.gov/imo/media/doc/Koh_Testimony.pdf.

65 One Piece at a Time: The 'Accumulation of Events' Doctrine and the 'Bloody Nose' Debate on North Korea, pristup 1. travnja 2021., https://www.lawfareblog.com/one-piece-timeaccumulation-events-doctrine-and-bloody-nose-debate-north-korea.

66 Christian Henderson, „Non-state Actors and the Use of Force”, u: Non-state Actors in International Law, ur. Math Noortmann, August Reinisch i Cedric Ryngaert (Oxford: Hart Publishing, 2004.), 86.

67 Gray, International Law and the Use of Force, 155.

68 James A. Green, „The Ratione Temporis Element of Self-Defense”, Journal on the Use of Force in International Law 2, br. 1 (2015): 97.

69 ICJ Reports 1986, para. 231. 
presude ne bi se moglo zaključiti da je Sud namjeravao potvrditi teoriju kumuliranih događaja. ${ }^{70}$ Konačno, u sporu između Kameruna i Nigerije, Kamerun je tvrdio da bi se niz graničnih incidenata Nigerije trebalo promatrati kumulativno, dok je Nigerija, suprotno tome, tvrdila da bi se incidenti trebali promatrati zasebno. Sud je smatrao da niti jedna od strana nije u dostatnoj mjeri dokazala svoje tvrdnje. ${ }^{71}$

Međunarodni sud, vidimo, propustio je izjasniti se o teoriji kumuliranih događaja. Slično se postavilo i Vijeće sigurnosti, osvrćući se u svakom slučaju tek na konkretne događaje, a ne i na načelnu primjenjivost ove teorije. ${ }^{72}$ Pravni su autori podijeljeni oko ovog pitanja. Dok neki od njih smatraju da napadačka namjera manifestirana kroz niz prethodno počinjenih napada daje osnovu za samoobranu protiv sljedećeg očekivanog napada, ovdje se svakako susrećemo s problemom imanentnim preemptivnoj samoobrani, odnosno s nemogućnošću izvjesnog utvrđivanja hoće li budući napad uopće nastupiti i kada. Stoga se čini ispravnim zaključak kako je „pristup kumuliranih događaja problematična osnova za pozivanje na samoobranu, ukoliko ne uključuje trenutačni ili neposredni oružani napad“. ${ }^{73}$ Usporedimo li ovaj zaključak s Bethlehemovim kriterijima, čini se da se nalazimo u začaranom krugu - neposrednost postoji ako, između ostaloga, postoji niz prethodno počinjenih napada, a samoobrana u slučaju prethodno počinjenih napada postoji ako je očekivani napad neposredan. To je, čini nam se, stoga što se u argumentacijama različitih autora miješaju dva različita poimanja neposrednosti: u prvom se slučaju neposrednost shvaća kao kauzalna kategorija, a u drugome kao vremenska kategorija.

\section{ZAKLJUČAK}

Zbog pojave prijetnji modernog doba, kao što su terorizam, oružje za masovno uništenje i cyber napadi, javile su se tendencije redefiniranja do tada postojećega koncepta neposrednosti samoobrane. Prema tradicionalnom konceptu neposrednosti, samoobrana je dopuštena kod neposredno predstojećeg napada, dakle onog napada koji je vremenski vrlo blizak i za kojega postoji visoki stupanj izvjesnosti da će se u skoroj budućnosti materijalizirati. S obzirom na specifičan karakter prijetnji suvremenog vremena, postavilo se pitanje mogu li se države učinkovito obraniti ukoliko slijede strogo temporalno definirani zahtjev neposrednosti. U svjetlu takvih nedoumica, neke države i pravni pisci zagovaraju izmijenjeni koncept neposrednosti, prema kojemu on ne bi podrazumijevao samo vremensku komponentu samoobrane, već bi se procjenjivao prema čitavom nizu okolnosti, kao što su težina prijetećeg

70 Oil Platforms (Islamic Republic of Iran v. United States of America), Judgment, ICJ Reports, 2003, para. 64.

71 Land and Maritime Boundaries between Cameroon and Nigeria (Cameroon v Nigeria: Equatorial Guinea Intervening), Judgment, ICJ Reports 2002, para. 323-324.

72 Reakciju Vijeća sigurnosti u odnosu na neke od oružanih akcija kojima su države odgovarale na niz sporadičnih napada vidi u: Higginbotham, F. Michael, „International Law, the Use of Force in Self-Defense, and the Southern African Conflict", Columbia Journal of Transnational Law 25, br. 3 (1987): 561.

73 Noam Lubell, Extraterritorial Use of Force against Non-state Actors (Oxford: Oxford University Press, 2010.), 54. 
napada, težina njegovih posljedica, postojanje ustaljenog obrasca napada $\mathrm{i}$ drugih. Temeljno pitanje na koje bi prilikom procjene neposrednosti, stoga, trebalo dati odgovor nije je li protupravni napad vremenski blizak, već je li samoobrana nužna baš u tom trenutku kako bi se osujetio neki budući napad.

Ako se napusti neposrednost kao vremenska kategorija, pitanje je što bi neposrednost onda trebala predstavljati. Različiti autori i predstavnici država ponudili su, vidjeli smo, kriterije prema kojima bi se njezino postojanje trebalo procjenjivati. No, primjena je tih kriterija problematična. Naime, ako protupravni napad ne mora nužno biti vremenski predstojeći, već je, tzv. neposrednost moguće zadovoljiti i ispunjavanjem nekih drugih uvjeta, postavlja se pitanje što je tu uopće „neposredno“. Takvim pristupom, čini se, ne samo da se koncept neposrednosti proširuje, već ga se de facto i ukida. Smatramo, stoga, da su transparentniji oni autori koji otvoreno zagovaraju eliminiranje zahtjeva neposrednosti iz procjenjivanja opravdanosti samoobrane ${ }^{74}$ od onih koji navedeni zahtjev do te mjere proširuju da on praktički gubi smisao i samostalnu primjenjivost.

Eliminiranje neposrednosti, bilo ono otvoreno ili prikriveno, otvara put prihvaćanju preemptivne samoobrane. Teško je povući jasnu granicu između preemptivne samoobrane, za koju će većina država reći da nije prihvatljiva, i proširenoga koncepta neposrednosti, kojega neke od njih promiču. Glavni čimbenik razlikovanja samoobrane protiv neposredno predstojećeg napada i one protiv dalekih i neizvjesnih prijetnji upravo je neposrednost. I izvjesnost napada uvelike je vezana uz neposrednost - ako je očekivani napad vremenski blizak, izvjesnije je da će nastupiti. S druge strane, kod vremenski dalekog napada, veća je vjerojatnost da će se u međuvremenu dogoditi nešto što će eventualno spriječiti njegovo nastupanje.

Bojazan od novih prijetnji, njihove nepredvidivosti i razornog učinka, razumljivo dovodi u pitanje primjerenost tradicionalnoga shvaćanja neposrednosti. No, i u odnosu na ove prijetnje mogu se razlikovati situacije u kojima postoje dokazi o pripremanju konkretnog napada, od onih u kojima postoji tek općenita prijetnja. U prvom slučaju, zahtjev neposrednosti mogao bi biti ispunjen. Uz to, ne treba zaboraviti da samoobrana nije jedini način borbe protiv navedenih prijetnji - mjere provođenja zakona trebale bi biti primarni oblik odgovora na njih.

Jasno je da bilo koji slučaj akcije u odnosu na neposredno predstojeći napad, čak i kada se neposrednost shvaća kao isključivo vremenska kategorija, nosi sa sobom problem utvrđivanja sa sigurnošću hoće li očekivani napad nastupiti ili ne. Tu će od presudne važnosti biti mogućnost dokazivanja postojanja jasnih indikacija o nadolazećem napadu, a ne tek davanje izjave relevantnih predstavnika države da je takav napad prijetio (primjerice pri ubojstvu Sulejmanija). Mogućnost je pogrešne procjene, naravno, moguća, no kod bilo kojeg oblika preventivne samoobrane nema zapravo mogućnosti provjere je li procjena bila valjana ili ne, tj. bi li protupravni napad bio nastupio ili ne.

U ovom je trenutku teško procijeniti ima li shvaćanje o dopustivosti samoobrane u slučaju neposredno predstojećeg napada prevagu u odnosu na ono o dopustivosti

74 Fritz Allhoff, „Self-Defense without Imminence“, American Criminal Law Review 56, br. 4 (2019): 1527. 
samoobrane isključivo u slučaju već započetog napada. Čini nam se da je danas više zastupljeno mišljenje da je samoobrana protiv neposredno predstojećega napada dopuštena. Možda je pojava koncepta preemptivne samoobrane doprinijela tome. Naime, iako sam taj koncept nije opće prihvaćen, možda je utjecao na šire prihvaćenje toga, možemo reći, umjerenog stajališta prema samoobrani, dakle, ni krajnje restriktivnog ni krajnje ekstenzivnog. Možemo, međutim, zaključiti da se potpora shvaćanju samoobrane kao dopuštene u slučaju neposredno predstojećeg napada temelji na shvaćanju neposrednosti kao vremenske kategorije. Za sada, proširenje koncepta neposrednosti ostaje tek inicijativa manjeg broja država i nema većega utjecaja na njegov dosadašnji sadržaj. Ostaje vidjeti kako će države reagirati na moderne prijetnje i hoće li neka eventualna postupanja sukladno s proširenim shvaćanjem neposredno predstojećeg napada dati poticaj nastanku novog običaja.

\section{LITERATURA}

Knjige i članci:

1. Akande, Dapo i Thomas Liefländer. „Clarifying Necessity, Imminence and Proportionality in the Law of Self-defense". American Journal of International Law 107, br. 3 (2013): 563-570.

2. Allhoff, Fritz. „Self-Defense without Imminence“. American Criminal Law Review 56, br. 4 (2019): 1527-1552.

3. Arend, Anthony Clark i Robert J. Beck. International Law and the Use of Force: beyond the UN Charter Paradigm. London, New York: Routledge, 1993.

4. Bethlehem, Daniel. „Self-Defense Against an Imminent or Actual Armed Attack by Nonstate Actors". American Journal of International Law 106, br. 4 (2012): 770-777.

5. Bowett, Derek W. Self-Defense in International Law. New York: Frederic A. Praeger, 1958.

6. Boyle, Francis A. „Military Responses to Terrorism”. Proceedings of American Society of International Law 81 (1987): 288.

7. Boyle, Joe. „Making Sense of Self-Defence in the War on Terror“. Journal on the Use of Force and International Law 1, br. 1 (2014): 55-79.

8. Brownlie, Ian. International Law and the Use of Force by States. New York, London: Oxford University Press, 1963.

9. Cassese, Antonio (ur.). The Current Legal Regulation of the Use of Force. Dordrecht: Martinus Nijhoff Publishers, 1986.

10. Cohan, John Alan. „The Bush Doctrine and the Emerging norm of Anticipatory SelfDefense in International Law“. Pace International Law Review 15, br. 2 (2003): 283-357.

11. Deklaracija o načelima međunarodnog prava o prijateljskim odnosima i suradnji između država u skladu s Poveljom UN, GA Res 2625 (XXV), 1970.

12. Dinstein, Yoram. War, Aggression and Self-Defense. Cambridge: Cambridge University Press, 2012.

13. Fidler, David P. „International Law and Weapons of Mass Destruction: End of the Arms Control Approach?". Duke Journal of Comparative \& International Law 14 (2004): 3988.

14. Gačić, Milica. Englesko-hrvatski rječnik prava, međunarodnih odnosa, kriminalistike $i$ forenzičnih znanosti, kriminologije i sigurnosti. Zagreb: Naklada Ljevak, 2004.

15. Gill, Terry D. „The Temporal Dimension of Self-Defense: Anticipation, Pre-emption, Prevention and Immediacy". Journal of Conflict and Security Law 11, br. 3 (2006): 113155. 
16. Gray, Christine. International Law and the Use of Force. New York: Oxford University Press, 2008.

17. Green, James A. „The Ratione Temporis Element of Self-Defense”. Journal on the Use of Force in International Law 2, br. 1 (2015): 97-118.

18. Hathaway, Oona. A. et al. „The Law of Cyber-Attack”. California Law Review 100, br. 4 (2012): 817-885.

19. Hayward, Ryan J. „Evaluating the Imminence of a Cyber Attack for Purposes of Anticipatory Self-Defense". Columbia Law Review 117 (2017): 399-434.

20. Henkin, Louis et al. Right v. Might: International Law and the Use of Force. New York: Council on Foreign Relations Press, 1991.

21. Higginbotham, F. Michael. „International Law, the Use of Force in Self-Defense, and the Southern African Conflict". Columbia Journal of Transnational Law 25, br. 3 (1987): 561-572.

22. Kesan, Jay P. i Carol M. Hayes. „Mitigative Counterstriking: Self-Defense and Deterrence in Cyberspace". Harvard Journal of Law and Technology 25, br. 2 (2012): 417.

23. Lubell, Noam. Extraterritorial Use of Force against Non-state Actors. Oxford: Oxford University Press, 2010.

24. Lubell, Noam. „The Problem of Imminence in an Uncertain World”. U: The Oxford Handbook of the Use of Force in International Law, ur. Marc Weller, 697-719. Oxford: Oxford University Press, 2015.

25. Noortmann, Math, August Reinisch i Cedric Ryngaert (ur.). Non-state Actors in International Law. Oxford: Hart Publishing, 2004.

26. Randelzhofer, Albrecht. „Article 51". U: The Charter of the United Nations - A Commentary, ur. Bruno Simma. Oxford, New York: Oxford University Press, 1995.

27. Reisman, W. Michael i Andrea Armstrong. „The Past and Future of the Claim of Preemptive Self-Defense". American Journal of International Law 100, br. 3 (2006): 525-550.

28. Rockefeller, Mark L. „The „Imminent Threat Requirement for the Use of Preemptive Military Force: Is it Time for a Non-temporal Standard?". Denver Journal of International Law and Policy 33 (2004): 131-149.

29. Schmitt, Michael N. „Preemptive Strategies in International Law”. Michigan Journal of International Law 24, br. 2 (2003): 513-548.

30. Schmitt, Michael. „Counter-Terrorism and the Use of Force in International Law”. U: International Law Studies, ur. Borch, F.L., Wilson, P.S. 79, 7-73.

31. Thomas M. Franck. Recourse to Force: State Action against Threats and Armed Attacks. Cambridge, New York: Cambridge University Press, 2002.

32. Tsagourias, Nicholas. „Chapter 2: The Tallinn Manual on the International Law Applicable to Cyber Warfare: A Commentary on Chapter II - The Use of Force". Yearbook of International Humanitarian Law 15 (2012): 19-43.

33. Warren, Aiden i Ingvild Bode. „Altering the Playing Field: The US Redefinition of the Use of Force". Contemporary Security Policy 36, br. 2 (2015): 174-199.

Međunarodni ugovori:

1. Povelja Ujedinjenih naroda, Narodne novine - Međunarodni ugovori, br. 15/93.

Sudska praksa:

1. Armed Actvities on the Territory of the Congo (DR Congo v. Uganda), ICJ Reports, 2005.

2. Gabčykovo-Nagymaros Project Case (Hungary v. Slovakia), Judgment, ICJ Reports, 1997.

3. Land and Maritime Boundaries between Cameroon and Nigeria (Cameroon v Nigeria: Equatorial Guinea Intervening), Judgment, ICJ Reports 2002.

4. Military and Paramilitary Activities in and Against Nicaragua (Nicaragua v. United States of America), Merits, Judgment, ICJ Reports 1986. 
5. Oil Platforms (Islamic Republic of Iran v. United States of America), Judgment, ICJ Reports, 2003.

Vrela s interneta:

1. A More Secure World: Our Shared Responsibility, Report of the Secretary-General's High-level Panel on Threats, Challenges and Change (2004). Pristup 10. veljače 2021., https://www.un.org/ruleoflaw/files/gaA.59.565 En.pdf

2. Attorney General's speech at the International Institute for Strategic Studies. Pristup 15. ožujka 2021., https://www.gov.uk/government/speeches/attorney-generals-speech-at-theinternational-institute-for-strategic-studies

3. Authorization for Use of Military Force after Iraq and Afghanistan. Pristup 25. ožujka 2021., https://www.foreign.senate.gov/imo/media/doc/Koh_Testimony.pdf

4. Cambridge Dictionary. Pristup 15. siječnja 2021., https://dictionary.cambridge.org/ dictionary/english/imminent

5. Chatham House Principles of International Law on the Use of Force by State in Selfdefense. Pristup 18. ožujka 2021., https://www.chathamhouse.org/sites/default/files/ publications/research/2005-10-01-use-force-states-self-defence-wilmshurst.pdf

6. In Larger Freedom: Towards Development, Security and Human Rights for All, Report of the Secretary-General, 124. Pristup 11. veljače 2021., https://www.un.org/en/events/ pastevents/in_larger_freedom.shtml

7. International Law and the Use of Force. Pristup 22. ožujka 2021., https://legal.un.org/avl/ pdf/ls/Wood_article.pdf

8. Leiden Policy Recommendations on Counter-terrorism and International Law. Pristup 22. ožujka 2021., https://scholarlypublications.universiteitleiden.nl/access/ item\%3A3145048/view

9. One Piece at a Time: The 'Accumulation of Events'Doctrine and the 'Bloody Nose'Debate on North Korea. Pristup 1. travnja 2021., https://www.lawfareblog.com/one-piece-timeaccumulation-events-doctrine-and-bloody-nose-debate-north-korea

10. Remarks of John O. Brennan, "Strengthening Our Security by Adhering to our Values and Laws ". Pristup 10. ožujka 2021., https://obamawhitehouse.archives.gov/the-pressoffice/2011/09/16/remarks-john-o-brennan-strengthening-our-security-adhering-ourvalues-an

11. Report of the Independent International Fact-finding Mission on the Conflict in Georgia, vol. 2. Pristup 19. siječnja 2021., https://www.mpil.de/files/pdf4/IIFFMCG_Volume_II1. pdf

12. Report of the Special Rapporteur on Extrajudicial, summary or arbitrary executions, Use of Armed Drones for Targeted Killings, A/HRC/44/38. Pristup 23. veljače 2021., https:// undocs.org/en/A/HRC/44/38

13. Report on the Legal and Policy Frameworks guiding the United States' Use of Military Force and Related National Security Operations. Pristup 12. ožujka 2021., https://www. justsecurity.org/wp-content/uploads/2016/12/framework.Report_Final.pdf

14. The National Security Strategy of the United States of America, 2002. Pristup 5. ožujka 2021., https://2009-2017.state.gov/documents/organization/63562.pdf

15. The National Security Strategy of the United States of America, 2006. Pristup 8. ožujka 2021., https://georgewbush-whitehouse.archives.gov/nsc/nss/2006/

16. The Right of Self-Defence against Imminent Armed Attack in International Law. Pristup16. ožujka 2021., https://www.ejiltalk.org/the-right-of-self-defence-against-imminent-armedattack-in-international-law/

17. The Soleimani Strike and Self-defense against an Imminent Armed Attack. Pristup 20. veljače 2021., https://www.ejiltalk.org/the-soleimani-strike-and-self-defence-against-animminent-armed-attack/ 
18. Trump says Soleimani plotted 'imminent' attacks, but critics question just how soon. Pristup 13. siječnja 2021., https://www.reuters.com/article/us-iraq-security-blastintelligence-idUSKBN1Z228N

19. US Department of State Archive: The Bush's Administration Non-Ploriferation Policy: Successes and Future Challenges. Pristup 5. ožujka 2021., https://2001-2009.state.gov/t/ us/rm/31029.htm

20. World reacts to US killing of Iran's Qassem Soleimani in Iraq, AlJazeera. Pristup 25. veljače 2021., https://www.aljazeera.com/news/2020/1/3/world-reacts-to-us-killing-ofirans-qassem-soleimani-in-iraq 


\section{Petra Perišić*}

\section{Summary \\ THE IMPACT OF MODERN-DAY THREATS ON THE MEANING OF IMMINENCE IN THE CONTEXT OF THE STATE'S RIGHT TO SELF-DEFENCE}

An emergence of modern threats, such as terrorism or weapons of mass destruction, has led to the reexamining of the traditional understanding of an, imminent attack", as a precondition of a lawful self-defence. Understanding of "imminence" as a temporal category has come under scrutiny due to the unpredictable character of modern threats and the impossibility of determining the exact moment in which they will materialize. This has led to redefining ,imminence“ by some scholars and states. Imminence is thus not perceived as an exclusively temporal category, but is being assessed with regard to different factors. This paper deals with the impact of new security threats on the notion of "imminence" and discusses whether the meaning of "imminence" has been changed and, if yes, how that influences the states' right to self-defence.

Keywords: imminent attack; imminence; anticipatory self-defense; preemptive self-defense; terrorism; weapons of mass destruction; cyber attacks.

* Petra Perišić, Ph.D., Assistant Professor, University of Rijeka, Faculty of Law; petra.perisic@ pravri.uniri.hr. ORCID: https://orcid.org/0000-0082-8529-0152. 